\title{
The Closing of the Door of Ijtihad and the Application of the Law ${ }^{1}$
}

This panel's center of gravity is Islamic legal theory and doctrine, particularly usül al fiqh. In this room are many of the West's leading scholars in this field. This puts me out of step, for my work leads me to study fiqh and usül al fiqh chiefly from the viewpoint of their application, an approach that is the result of spending several years in Saudi Arabia studying the role of figh and the ulema in the Islamic legal system. I wish to submit, however, that there are a number of doctrinal problems to which a study of the law's application and practice or, in other words, a study of the legal system, stands to contribute a great deal. The closing of the door of ijtihad, which I intend to discuss, is such an issue.

But first let me make some general points to support the general suggestion I have just made. In western studies of figh, we have often omitted, justifiably or not, any consideration of the law's application. Among the valid justifications for doing so is the very vastness of the doctrinal corpus. Another is that to get basic data on the law's historical application is far more difficult than finding its black-letter doctrine. Other justifications are more questionable. For one, we have often made certain assumptions, which-stating them with due exaggeration-hold that Islamic law, since it became stagnant at an early period, was usually ignored in practice. As a result of this, it is often maintained, figh retreated into the ideal world of scholarship while the application of the law fell under the sway of arbitrary and despotic rulers. Approaching the law with such an impression, however much in the background, scholars of Islamic law have, not surprisingly, spent little time on its application.

This last justification for ignoring the law's application is now, I believe, rapidly eroding due to the efforts of scholars on many different fronts. Some, notably Professor Hallaq, are at work countering the exaggerated idea of the "closing of the door of ijtihad," a phrase used to convey the idea that fiqh became utterly stultified at an early stage. ${ }^{2}$ Other scholars are examining late Shari'ah court records and legal documents

'Paper delivered at the American Oriental Society Conference, Cambridge, Massachusetts, 13 March 1992.

${ }^{2}$ See Wael B. Hallaq, "Was the Gate of Ijtihad Closed?," International Journal of Middle Eastern Studies 16 (1984). 
and are finding that relevant fiqh doctrines were scrupulously applied. Still others are tracing extensive developments in fiqh law, in the interstices of doctrine, and in genres of fiqh literature, particularly fatâw $\bar{a}$, which are hierarchically lower than the mutūn, or basic texts of the legal schools. Lastly, there are scholars studying Shari'ah applications in traditional contemporary societies.

There is a single theme, I submit, that usefully integrates research into the law's application: the profound tension or dialectic, apparently endemic in the Islamic legal venture, between the ulema and the ruler. While the former are the bearers and advocates of fiqh, the latter is the inheritor of another principle-namely power-which is as indispensable to the fulfillment of the Islamic legal ideal as is figh itself. The ruler's very indispensability lends him an indefeasible legitimacy, which can be countered by the ulema only with difficulty. Let us designate this legitimacy, as it concerns the operation of the legal system, by the ulema's own term: siyāsah. The structure of an Islamic legal system arises most essentially from the complex interaction of these two legitimacies and institutions-siyassah and ruler on the one hand, and fiqh and the ulema on the other-as they enter into relations of cooperation and competition.

My suggestions here run counter to the tendency in Muslim and nonMuslim writings on fiqh to neglect the siyäsah principle found in the law. For example, we often represent all legislation and adjudication originating in siyāsah as "extra-Shari 'ah" by definition. This is to confuse fiqh (the human endeavor to know God's law, as represented in the work of the ulema) with the Shari'ah (the all-encompassing divine order for human life) and thereby to accept too uncritically the ulema's own, sometimes partial, representation of the Shari'ah legal system.

Drawing on such thoughts, I suggest that we augment efforts to evaluate fiqh controversies, even those involving $u s ̧ u ̈ l$ al fiqh, for their significance with regard to the law's application. We should situate such controversies within the theory of the legal system as a whole and also, ideally, within the context of the particular Islamic legal system in question. To this end, we must use all tools at our command, among them fiqh theory (including the theory of qad $\bar{a}$ ' [adjudication], ift $\bar{a}$ ' [authoritative opinion] and siyäsah), historical explanation, as well as legal, comparative, and sociological method.

Turning to the "closing of the door of ijtihad," I view this as an example of a problem that is likely to benefit from the approach just outlined. Let us begin with a rather obvious point: how natural, and how seemingly necessary, the adoption of a theory like the "closing of the door" is to the operation of the Islamic legal system. 
To appreciate this, recall the theory and the role of $q a d \bar{a}^{\prime}$ in the larger legal system. Books of figh strenuously make the point that qadä' is rooted in ijtihad and that ijtihad provides the sole ground for the religious legitimacy of qad $\vec{a}^{\prime}$. Of the famous three $q \bar{a} d \bar{i}$ of the hadith-of whom two are in the Fire and one is in Paradise-what saves the latter is his sincere ijtihad. The answer to the profound moral dilemma facing the qädi-how to judge in the name of God's justice when God's law is uncertain (zanni) -is nothing but ijtihad.

This belief that ijtihad is at the root of $q a d \bar{a}^{\prime}$ has led to many peculiar tenets associated with the theory of qadia'. The most obvious one is that the $q \bar{a} d \bar{i}$ must be qualified to practice ijtihad (mujtahid). If this is not the case, his appointment is void, and so are all of his judgments, even if they are correct. Only the Hanafi legal school disputes this view, for it allows a lesser light to be appointed $q \bar{a} d \bar{l}$ on the condition that he consult one more knowledgeable.

A second tenet is that the $q \bar{a} d \bar{i}$ must be free to rule according to "that to which his ijtihad leads him." In the ardent search for God's truth that is ijtihad, nothing but the revealed texts and the concrete facts of the case ought to constrain the qâa $\vec{i}$ s conscience. If any other influence intervenes-such as a ruler's command to apply such and such a rule-ijtihad is not attained, the qädi personally risks hell-fire, and his judgment is void. Likewise, past decisions or precedents, whether his own or somebody else's, cannot constrain him, for he is supposed to conduct a fresh ijtihad for each case, no matter how routine.

Ijtihad also determines a third tenet: that no qādi has priority over any other in matters of truth. Once a case has been decided by ijtihad, it cannot be reversed by another authority.

If this conception of qad $\bar{a}^{\prime}$-so idealizing, individualistic, multifarious, and unpredictable-were given full scope, Islamic legal systems would face great practical difficulty. In fact, such complaints are recorded very early in the 'Abbāsid era. In a famous treatise, Ibn al Muqaffa' (d. c. $140 \mathrm{AH} / 757 \mathrm{CE}$ ) protested the

multiplicity of mutually contradictory [legal] judgments. This multiplicity has become a serious matter, affecting lives, sexual rights, and property. Life or sexual union may be permitted in Hirah while it is forbidden in Küfah . . . . All this while no group, from the people of Iraq or the Hijāz, can inquire into this without becoming confirmed in conceit with what they have, and slighting the other party.

${ }^{3}$ Ibn al Muqaffa;, Treatise of the Companions," in Rasā'il al Bulaghä, ed. Mubammad Kurd "Ali, 4th ed. (Cairo: 1374 AH/1954 CE), 126-7. 
He recommended to the caliph that the latter examine all of the conflicting rulings on each issue, select among them, and then codify his choices into a written law. This proposal was defeated, and with it a bid that the ruler-wielding the authority of siyassah with its breadth, flexibility, responsiveness to utility, and, above all, powers of compulsion-should seize control of legislation and thereby replace the ulema and their rigorously individualistic and conscience-based ijtihad. At the time Ibn al Muqaffa' wrote, the Hanafi school was already in formation around Abū Hanifah, and with it the practices of taqlid and school discipline that would lead eventually to widespread limits on ijtihad.

By now my hypothesis should be clear. It is, in essence, that restrictions on ijtihad were adopted when the ulema, knowing that their theory of law caused practical problems in actual legal systems, made the concessions necessary to ensure that their fiqh would survive and could compete successfully against contending principles in the legal system, chiefly siyäsah. Thus "closing of the door" was one piece in a complex mechanism of ulema doctrines and institutions designed to protect and advance, in competition mainly with the ruler, their vision of law and legitimacy.

This hypothesis can explain a paradox noted by Hallaq. He observes the oddity that scholars should declare ijtihad nonexistent, while they at the very same time acclaim certain fuqaha $\bar{a}^{\prime}$ of their own age as $m u j$ tahids, exercising ijtihad. The explanation for this paradox lies in the link between the "closing of the door" and the day-to-day operation of the legal system: the doctrine was intended to constrain rank-and-file qädis and muftis, not the elite. Elite scholars, who possessed the capabilities and the courage to exercise ijtihad as well as the prestige to make it stick, could breach the barrier. ${ }^{4}$ Examples exist even among the late Hanafis. ${ }^{5}$

Let us now leave these generalities and look at a specific text that is partly illustrative of my points: al Māwardī's al Ahkām al Sultānīyah. In this book, the author attempted to assert a complete fiqh doctrine for both public and constitutional law. Written after severe shocks to the legitimate caliphate, it seemingly can be read as a tentative blueprint for advancing the authority of fiqh and the ulema over and against that of siyäsah and the state. Dealing as he does with many highly sensitive

${ }^{4}$ This is but one example of the ulema's tendency to hierarchize truth, mediating theory and practice via doctrines and practices arranged in ranking and qualified epistemologically.

SIbn ‘Ābidin (d. 125 AH / 1836 CE), "Sharh al Manzumah al Musammāh bi 'Uqūd Rasm al Muftī," in Majmū 'at Rasā'il Ibn 'Ābidīn (Beirut: Dār Ihyyā' al Turāth al 'Arabī, n.d.), 32, defending the ijtihad of the great Hanafi Ibn al Humām (d. 861 AH / 1456-57 CE). 
issues concerning the division of power between siyāsah and fiqh, al Māwardī at times uses ambiguity, clever phrasing, or unspoken associations to convey his points.

This seems to be his approach while discussing the issue of the $q \bar{a} d \vec{\imath} \mathrm{s}$ freedom to exercise ijtihad. In a section on the qualifications of a $q \bar{a} d \underline{i} \bar{i}$, al Māwardī accepts the majority view, holding that the $q \bar{a} d \hat{l}$ must be a mujtahid, that the appointment (wiläyah) of a non-mujtahid is void, and that the latter's judgments are to be rejected. He then treats various questions concerning whether a $q \bar{a} d \hat{d} \hat{\imath} \mathrm{s}$ judgments must conform to the positions of a single school. He writes: "Some legal scholars" note that he is not dealing yet with the ruler-

have prohibited one who belongs to a certain school from judging by any other, so that a Shäfi' 1 is prohibited from judging by the view of $A b \bar{u}$ Hanīah, and the Hanafī is prohibited from judging by the school of al Shāfi ' $\overline{1}$, if his ijtihad leads to [the latter holding]. This is because of the suspicion and partiality in cases and judgments attributable to such a practice. If he judges by a school from which he [is not allowed to] depart, this better prevents suspicion and is more agreeable to the litigants. Even though good policy (siyāsah) requires (taqtadi) [this result], the rulings of the Shari'ah do not obligate it (la tüjibuhu), because taqlid as to [these rulings] is prohibited, and ijtihad as to them is requisite (mustahaqq). ${ }^{6}$

Among the more obvious objections to allowing judges to exercise ijtihad on a broad scale is that this would both deny predictability to litigants and open the door to judicial arbitrariness and corruption. Here, al Māwardī alludes to these objections and acknowledges that, due to them, the practical needs of the legal system-labelled siyassah- "require" that judges do not vary from a particular school. He then goes on to declare, with a delicate choice of words, that despite the demands of siyāsah, the Shari ah does "not obligate" this result, since ijtihad is "requisite" (mustahaqq). ${ }^{7}$

Al Māwardī's discussion ends with a long treatment of the problem that is probably his chief concern: whether a ruler can make a qāadi s ap-

${ }^{6} \mathrm{Al}$ Māwardī (d. $450 \mathrm{AH} / 1058 \mathrm{CE}$ ), al Ahkām al Sultānīyah wa al Wilāyāt al Dīñyah (Beirut: Dār al Kutub al 'Ilmīyah, 1398 AH / 1978 CE), 67-8.

${ }^{7}$ As he had explained earlier in the section, the Shari'ah's application requires one who is "committed to the truth (multazim al haqq) and not one who merely enforces it (düna mulzimih)." 
pointment conditional upon his agreeing to judge only by a certain school. Such a condition, al Mãwardī declares, is void. As to whether the appointment itself is void, he explains how this varies according to the form used and to the school. (Interestingly, the Hanafi school is most willing to uphold the appointment.)

This was in the fifth hijri century. As time progresses, we find differing formulations dealing with the freedom of $q \bar{a} d \bar{i}$. As the conception spreads that mujtahids are unavailable, and therefore that $q \bar{a} \bar{d} \bar{i}$ can no longer meet the qualifications of office, qad $\bar{a}^{\prime}$ works begin to make provision that $q \bar{a} d \bar{i} \bar{s}$ possessing much reduced qualifications and who can apply only the rulings of their own school are acceptable. However, these works still maintain that this result cannot be compelled by the ruler. ${ }^{8}$ Finally, with the Ottomans (if not before), we find the ruler reinforcing this outcome by his decree withdrawing jurisdiction from any judge who decides by other than the dominant Hanafi view. As we examine such positions over history, it is vital that we approach them with a lively sense of the roles they play in the actual legal systems of their time.

Frank E. Vogel Assistant Professor of Law Harvard University Cambridge, Massachusetts

${ }^{8}$ See, eg., Ibn Abī al Dam (Shāfi'īi, d. 642 AH / 1244 CE), Kitāb Adab al Qādī, ed. Mubyyī Halāl al Sirbān, 2 vols. (Baghdad: Maţba'at al Irshād, 1404 AH / 1984 CE), $1: 275-6,304$. 